\title{
Disparate In Vitro Inhibition of Adhesion of Enteropathogenic Escherichia coli RDEC-1 by Mucins Isolated from Various Regions of the Intestinal Tract
}

\author{
DAVID R. MACK AND PENNY L. BLAIN-NELSON \\ Departments of Pediatrics and The Center for Human Nutrition, University of Nebraska Medical Center, \\ Omaha, Nebraska 68198
} \begin{abstract}
ABST
Escherichia coli RDEC-1 (serotype $\mathrm{O} 15: \mathrm{H}-$ ) is a rabbit
enteropathogen in which in vivo enteroadherence is both site specific and age related. To determine whether these differences could be related to mucins, we evaluated inhibition of binding of $\mathrm{AF} / \mathrm{R} 1$ piliated RDEC-1 by mucins isolated from various segments of intestine of rabbits at different ages. Mucin was purified from intestinal crude mucus by cesium chloride serial ultracentrifugation. RDEC-1 was grown to promote the expression of hydrophobic mannose-resistant AF/R1 pili. Quantitation of in vitro bacterial binding was determined using a crystal violet colorimetric assay. In postweanling rabbits, inhibition of RDEC-1 binding by purified mucin derived from ileal segments $(45.1 \pm 2.6 \%$, mean \pm SEM) and proximal colonic segments $(46.0 \pm 5.5 \%)$ was less than purified mucins derived from jejunal segments $(70.0 \pm 2.0 \%)$ and distal colonic segments $(71.0 \pm$
\end{abstract}

$3.7 \%, p<0.05)$ of the intestinal tract. In all age groups, mucins derived from jejunal segments inhibited RDEC- 1 binding to a greater level than mucins derived from ileal segments. In addition, inhibition of binding by mucin derived from proximal small intestine of postweanling rabbits $(70.0 \pm 2.0 \%)$ was greater than that of weanling rabbits $(55.2 \pm 3.5 \%, p<0.05)$ with suckling rabbit inhibition $(62.1 \pm 3.5 \%)$ between these two levels. We conclude that mucin inhibition of RDEC-1 adhesion is both age and region related and therefore may contribute to both agerelated and site localization of bacterial infections of the intestinal tract. (Pediatr Res 37: 75-80, 1995)

\section{Abbreviations}

EPEC, enteropathogenic Escherichia coli

ANOVA, analysis of variance
Mucin is a high-molecular-weight glycoprotein synthesized and secreted by specialized epithelial cells (i.e. mucous cells) present within a number of body organ systems including the gastrointestinal tract. Mucin is characterized by its large size $\left(0.5 \times 10^{6}\right.$ to $\left.2.0 \times 10^{6} \mathrm{D}\right)$, high content of carbohydrates [>70\% (wt/wt)], and O-glycosidic bonds between $\mathrm{N}$ acetylgalactosamine and either serine or threonine residues in the peptide backbone (1). Mucin is the major organic constituent of mucus, and its presence determines both the physical and gel-forming properties of mucus (1).

Mucus covers most of the surface of the gastrointestinal tract. Thus, it is interpositioned between the luminal contents of the intestine and the epithelial cells of the host. Mucus is proposed to have a number of functions including cytoprotection of the stomach, lubrication of intestinal contents, and protection against infection (1). Mucus may protect the under-

Received January 25, 1994; accepted June 10, 1994.

Correspondence: David R. Mack, M.D., Combined Section of Pediatric Gastroenterology and Nutrition, University of Nebraska Medical Center, 600 South 42nd St., Omaha, Nebraska $68198-5160$.

Supported in part by a grant from the Edna Ittner Pediatric Research Support Fund and a grant from Clintec, Inc. lying intestinal mucosa by a number of mechanisms, including prevention of enteric pathogen adhesion to epithelial cells. Adhesion of bacteria to epithelial cells is a complex process involving both specific and nonspecific interactions (2) that are crucial for the development of toxin delivery, colonization, and subsequent invasion (3).

The noninvasive, nonenterotoxigenic rabbit enteropathogen Escherichia coli RDEC-1 (serotype O15:H-) (4) has been shown to adhere to epithelial cells of the distal small intestine and proximal colon. Weanling rabbits are particularly susceptible to this enteropathogen, but postweanling animals may also develop enterocolitis. In addition to binding to mucosal cells, the organisms are also present in the mucous layer overlying surface epithelial cells of the intestinal tract (5). RDEC-1 expressing AF/R1 pili have been previously shown to bind to crude mucus and purified mucin of rabbit ileum that have been immobilized on polystyrene wells (6). Previously, we showed that purified mucins derived from colonic segments of rabbits inhibit in vitro adhesion of RDEC-1, whereas other components of crude mucus do not (7). 
The composition of mucins varies from one region of the gut to another. For example, mucins derived from more distal regions of the gastrointestinal tract are larger or more aggregated and contain more protein with a unique amino acid profile compared with mucins purified from more proximal regions of the intestinal tract (1). Age-related variations in carbohydrate composition, amino acid composition and lectinbinding patterns of intestinal mucins have also been described $(8,9)$. Despite these histochemical and biochemical differences, there have not been studies to determine functional consequences. The aim of this study was therefore to examine the effects of mucins derived from various regions of the intestinal tract at different ages on bacterial attachment using an attaching and effacing rabbit diarrheal pathogen, E. coli strain RDEC-1.

\section{METHODS}

Preparation of soluble rabbit mucus. Soluble mucus was prepared from mucosa of various sections of the intestinal tract from eight postweanling male (weight $3 \mathrm{~kg}$ ), 10 weanling (5-wk-old), and 10 suckling (2-wk-old) New Zealand White rabbits (Smith's Rabbitry, Harlan, IA). Crude mucus from corresponding intestinal segments and ages were pooled to provide enough material from which adequate amounts of mucin could be purified for subsequent experimentation. Weanling and suckling rabbits were litter mates. Mucosa from the proximal third of the small intestine (jejunum) and the distal third of the small intestine (ileum) were used to prepare mucus from the animals of various ages. In postweanling rabbits, the proximal half of the large intestine (proximal colon) and distal half of the large intestine (distal colon) were also harvested. Animals were killed using intracardiac T-61 (Hoechst-Roussel Agri-Vet Co., Somerville, NJ) after intramuscular anesthesia with ketamine (Aveco Co., Fort Dodge, IA) and xylazine (Rugby Laboratories, Rockville Centre, NY). A midline abdominal incision was made to open the abdominal cavity, and the various sections of the intestinal tract were removed. The excised sections were washed with normal saline at $4^{\circ} \mathrm{C}$ and opened along the longitudinal axis. Mucosal scrapings were obtained by gently scraping the luminal surface with a glass slide. The scrapings were immediately weighed and placed into a solution of proteinase inhibitors $[100 \mathrm{~mL} / \mathrm{g}$ (wet weight)] to minimize proteolytic degradation of native mucins (10). The proteinase inhibitor solution contained $5 \mathrm{mmol} / \mathrm{L}$ EDTA (Sigma Chemical Co., St. Louis, MO), $5 \mathrm{mmol} / \mathrm{L}$ N-ethylmaleimide (Sigma), $2 \mathrm{mmol} / \mathrm{L}$ phenylmethylsulfonyl fluoride (Sigma), and $0.01 \%$ sodium azide (Sigma). Scrapings in solution were then homogenized in a Waring blender (Waring Products Division, New Hartford, CT) for $30 \mathrm{~s}$. The homogenate was then centrifuged at $30000 \times \mathrm{g}$ min at $4^{\circ} \mathrm{C}$ to remove pelleted cellular and particulate debris. The soluble supernatant from each of the various intestinal segments, defined in this study as crude mucus, was stored at $-70^{\circ} \mathrm{C}$ until use in subsequent purification.

Purification of goblet cell-derived mucin. Crude mucus was separated into its components including goblet cell-derived mucin by isopycnic ultracentrifugation, as described by Mantle and Allen (11). Brieffy, crude mucus was suspended in a solution of cesium chloride (Fisher Scientific, Plano, TX) to a starting density of $1.41 \mathrm{~g} / \mathrm{mL}$. The suspension was placed into 35-mL polyallomer centrifuge tubes (DuPont Co., Wilmington, $\mathrm{DE}$ ) and centrifuged in a Sorvall TFT 50.38 rotor (DuPont) at $105000 \times g$ for $48 \mathrm{~h}$ at $4{ }^{\circ} \mathrm{C}$. After ultracentrifugation, a needle was inserted to the bottom of centrifuge tubes, and eight fractions of equal volumes were collected using a peristaltic pump (Spectra/Chrom Macroflow, Spectrum Medical Industries, Houston, TX). The eight separate fractions were analyzed for buoyant density by refractometry (Abbe $3 \mathrm{~L}$, Milton Roy Co., Rochester, NY) and were found to range from $1.52 \mathrm{~g} / \mathrm{mL}$ in the heaviest buoyant density fraction to $1.32 \mathrm{~g} / \mathrm{mL}$ in the lightest fraction after both this first ultracentrifugation and a second ultracentrifugation. Buoyant density fractions were then placed into wetted cellulose dialysis tubing (SpectroPor 7, $50000 \mathrm{M}_{\mathrm{r}}$ exclusion; Spectrum Medical Industries) and dialyzed against deionized water for $48 \mathrm{~h}$ at $4^{\circ} \mathrm{C}$. Total protein concentration in each fraction was determined by the method of Lowry et al. (12) with BSA type V (Sigma) as standard. Glycoprotein content was determined using the periodic acidSchiff assay with analysis by measuring OD $555 \mathrm{~nm}$ (13). Porcine stomach mucin type III (Sigma) was used as standard to quantitate relative mucin glycoprotein levels. Nucleic acid content was determined by measuring OD $260 \mathrm{~nm}$ (14). As previously described $(1,7,15)$, fractions with a high content of glycoprotein versus total protein, a low nucleic acid content, and buoyant densities of approximately $1.45 \mathrm{~g} / \mathrm{mL}$ were then pooled and ultracentrifuged a second time in cesium chloride. After the second ultracentrifugation, those fractions with a high glycoprotein-protein ratio, low OD $260 \mathrm{~nm}$, and buoyant density between 1.47 and $1.41 \mathrm{~g} / \mathrm{mL}$ were then pooled and used in this study as purified mucin. All steps in the preparation of crude mucus and purified mucin were performed at $4^{\circ} \mathrm{C}$.

Compositional analysis of mucins. Amino acid analyses were performed by the Protein Core Facility at the University of Nebraska Medical Center using a Beckman 6300 amino acid analyzer (Beckman Instruments Inc., Palo Alto, CA). Briefly, the sample was hydrolyzed using $6 \mathrm{~mol} / \mathrm{L}$ hydrochloric acid in $1 \%$ phenol at $110^{\circ} \mathrm{C}$ for $24 \mathrm{~h}$. After hydrolysis, excess hydrochloric acid was removed under vacuum, and the sample was taken up in standard Beckman physiologic sample dilution buffer and chromatographed using Beckman physiologic buffers $\mathrm{A}, \mathrm{D}, \mathrm{E}$, and $\mathrm{F}$.

PAGE of mucins. SDS-PAGE of high-molecular-weight mucins was performed under nonreducing conditions according to the method of Laemmli (16) using a vertical slab system $(0.75 \mathrm{~mm} \times 8 \mathrm{~cm} \times 7.3 \mathrm{~cm})$ (Bio-Rad Laboratories, Richmond, CA). The separation gel contained $7.5 \%$ acrylamide, and the stacking gel contained $4 \%$ acrylamide. Mucin samples ( $7.5 \mu \mathrm{g}$ of protein) were mixed in an equal volume of $10 \%$ SDS buffer and electrophoresed through both the stacking and separating gels at a constant voltage $(200 \mathrm{~V})$ for $40 \mathrm{~min}$. The minigel was then stained with silver (Bio-Rad silver stain kit) according to the method of Merril et al. (17). Gels were calibrated with high-molecular-weight standards (Bio-Rad).

Bacteria and growth conditions. Stock cultures of RDEC-1 (serotype $\mathrm{O} 15: \mathrm{H}-$ ) were held on Trypticase soy agar slants 
(BBL Microbiology Systems, Cockeysville, MD) at $4^{\circ} \mathrm{C}$. Organisms were grown in static, nonaerated Penassay broth (Difco Laboratories, Detroit, MI) to promote the expression of mannose-resistant pili, previously designated AF/R1 (18). Expression of the pili was confirmed by Western blotting of sonicated bacterial proteins against $\mathrm{AF} / \mathrm{R} 1$ pilus-specific antiserum (data not shown) (19). The RDEC-1 were not serially passed, because serial passage promotes type 1 pilus expression (19). Strain M34, an isogenic mutant of RDEC-1 in which Tn5 insertions into the plasmid encoding for AF/R1 pili result in a loss of pilus expression (20), was used as a negative control for the adhesion assay. Outer membrane profiles of piliated RDEC-1 and M34 are similar after growth of the organisms in Penassay broth in both the presence and absence of an iron chelator (21). Therefore, in this study, M34 was grown in Penassay broth. Bacteria and antiserum were kindly provided by Dr. P. Sherman (The Hospital For Sick Children, Toronto, Canada).

Bacteria were harvested by centrifugation at $2500 \times g$ for 15 min. After two washes in sterile PBS (pH 7.4) at $25^{\circ} \mathrm{C}$, bacteria were resuspended in PBS at a concentration of $10^{10} / \mathrm{mL}$ as determined by measuring absorbance of bacteria at $600 \mathrm{~nm}$.

Bacterial adhesion assay. Adhesion of bacteria was examined using a modification of an in vitro method described by Shea and Williamson (22). Various amounts of bacteria suspended in $0.3 \mathrm{~mL}$ of PBS were added to wells of a 96-well polystyrene tissue culture plate (Immulon 4; Dynatech Laboratories, Chantilly, VA). After incubation for $1 \mathrm{~h}$ at $37^{\circ} \mathrm{C}$, nonadherent bacteria were removed by two washings with sterile PBS. To stain adherent bacteria, $300 \mu \mathrm{L}$ of $0.01 \%$ $\mathrm{wt} / \mathrm{vol}$ aqueous crystal violet dye (Sigma) were added to the wells and incubated at room temperature for $5 \mathrm{~min}$. To remove nonincorporated dye, wells were washed twice with PBS. Adherent bacteria that had incorporated the crystal violet were then lysed with a $2 \% \mathrm{wt} / \mathrm{vol}$ sodium deoxycholate (Sigma) detergent solution to release the dye from cell membranes into solution. Plates were then incubated while being shaken at room temperature for $1 \mathrm{~h}$ to ensure even distribution of the dye. Microtiter plates were then read on an EAR 340 AT microplate reader (SLT Instruments, Salzburg, Austria) at $570 \mathrm{~nm}$. Values were blanked against OD $570 \mathrm{~nm}$ readings of wells containing only lysed bacteria, sodium deoxycholate, and PBS. All samples were run in triplicate.

To examine the inhibitory effects of mucins purified from various regions of the intestinal tract at varying ages on bacterial binding to microtiter wells, various amounts of mucin were mixed with $10^{9}$ bacteria before their addition to microtiter wells. The total volume that was added to each well was 0.3 $\mathrm{mL}$. The adhesion assay the proceeded exactly as described above with the 1-h incubation and subsequent steps.

Statistics. Results are expressed as mean \pm 1 SEM unless otherwise indicated. Graphs represent $95 \%$ confidence intervals. Comparisons between two groups were determined using two-tailed unpaired $t$ test (23). Comparisons between multiple groups were done by using the Fisher protected leastsignificant-difference one-factor ANOVA at $95 \%$ confidence intervals (24).

\section{RESULTS}

Characterization of mucins. To evaluate both relative sizes of samples collected as purified mucins from various regions of the intestinal tract and purity of samples, $7.5 \mu \mathrm{g}$ of mucin protein were subjected to SDS-PAGE and staining with silver. Material collected as purified mucin from the proximal and distal colonic segments of postweanling rabbits did not enter the separating gels but was found at the stacking/separating gel interface. Mucin prepared from jejunal and ileal segments entered only the upper separating gels also to a level representing molecular weights of greater than $200 \mathrm{kD}$. In addition, no low-molecular-weight contaminants were visualized in these purified mucin preparations. These findings are consistent with previous published reports that higher molecular weight mucins are derived from colon than from other intestinal segments (1).

The major peptide backbone of intestinal mucins contains an enriched content of residues of the amino acids serine, threonine, and proline (1). Two minor regions of the mucin peptide core have relatively increased amounts of either aspartic acid and glutamic acid or glycine, alanine, and valine (1) residues. As shown in Table 1 , the amino acid composition of both major and minor peptide regions of mucins from both largeintestinal and small-intestinal segments was comparable with previous results $(1,7,15)$.

Mucin inhibition of bacterial binding. The binding of RDEC-1 to brush borders, crude mucus, purified mucins, and polystyrene wells has been previously shown to be dependent on expression of hydrophobic $\mathrm{AF} / \mathrm{R} 1$ pili $(7,21)$. Increasing numbers of AF/R1 piliated RDEC-1 and M34 in the inoculum as estimated by measuring the absorbance at OD $600 \mathrm{~nm}$ correlated directly with the number of live viable bacteria determined to be present by colony forming unit determinations (established in laboratory, data not shown), and OD 600 $\mathrm{nm}$ measurements were used subsequently to determine inoculum size. Increased adherence of bacteria to polystyrene as measured by absorbance at OD $570 \mathrm{~nm}$ in the crystal violet assay directly correlated with AF/R1 piliated RDEC- 1 inoculum size (Fig. 1). In contrast, increased numbers of M34 bacteria in the inoculum did not result in greater binding of M34 to the polystyrene wells (Fig. 1), thus confirming the importance of the presence of the AF/R1 pili binding to polystyrene wells that was used for our in vitro adhesion assay

Table 1. Amino acid composition of mucins

\begin{tabular}{lcccc}
\hline \multirow{2}{*}{ Age } & Mucin & \multicolumn{3}{c}{ Amino acid content (mol/100 mol) } \\
\cline { 3 - 5 } Suckling & source & Ser + Thr + Pro & Asp + Glu & Gly + Ala + Val \\
\hline \multirow{3}{*}{ Weanling } & J & 25 & 27.3 & 19.2 \\
Postweanling & I & 31.3 & 23.2 & 15.2 \\
& J & 27.9 & 25.3 & 15.3 \\
& I & 31.0 & 26.6 & 15.6 \\
& J & 37.5 & 20.2 & 12.8 \\
& I & 30.4 & 23.7 & 15.2 \\
& PC & 39.6 & 19.1 & 11.8 \\
& DC & 34.1 & 19.9 & 16.3
\end{tabular}

J, jejunum; I, ileum; PC, proximal colon; DC, distal colon; Ser, serine; Thr, threonine; Pro, proline; Asp, aspartic acid; Glu, glutamic acid; Gly, glycine; Ala, alanine; Val, valine. 


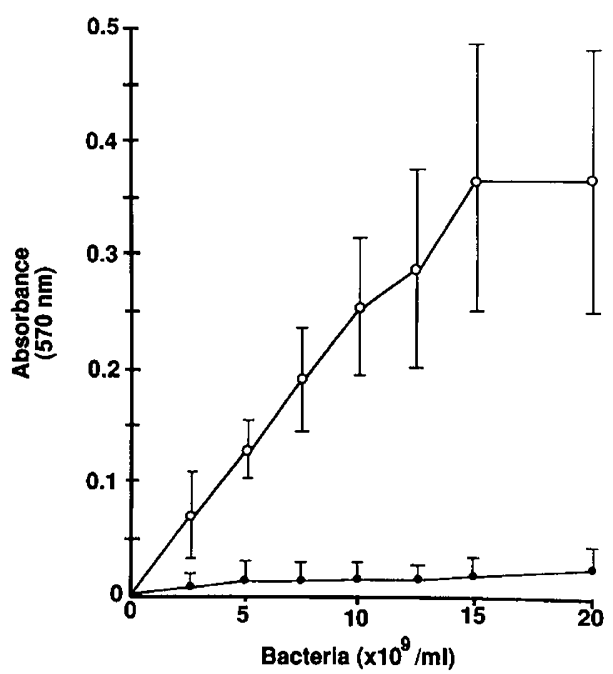

Figure 1. Characterization of crystal violet colorimetric assay. Differential binding of bacterial strains for the in vitro adhesion assay is shown. Significantly more AF/R1-piliated RDEC-1 (O) bound to the wells than when a non-AF/R1-piliated Tn5 mutant, strain M34 (-), was used in the adhesion assay. Results are expressed as mean \pm SEM of five experiments. All experiments were run in triplicate.

in these experiments. These data are similar to those data previously reported using ${ }^{3} \mathrm{H}$-thymidine to radiolabel bacteria to quantitate bacterial adhesion to polystyrene microtiter wells $(7,15)$.

Concentration-dependent inhibition of RDEC-1 binding was observed using purified mucin derived from all segments of the intestinal tract from all age groups. For example, using mucin derived from ileal segments of suckling rabbits, there was $14 \%$ inhibition of RDEC- 1 binding with $1 \mu \mathrm{g} / \mathrm{mL}$ mucin per well, $62 \%$ inhibition with $2.5 \mu \mathrm{g} / \mathrm{mL}$ mucin per well, and complete inhibition with $5 \mu \mathrm{g} / \mathrm{mL}$ mucin per well. As with suckling ileal mucin, there was virtually complete inhibition of bacterial adhesion with mucin protein concentrations of $5 \mu \mathrm{g} / \mathrm{mL}$ for mucins derived from other segments at the various ages of rabbits used. To evaluate relative differences of mucin inhibition of bacterial binding, comparisons between mucins derived from the various intestinal segments were therefore based on the concentration of mucin that would allow for relative differences to be evaluated, namely $2.5 \mu \mathrm{g} / \mathrm{mL}$ mucin protein, in adhesion assays.

When equal amounts of mucin (based on mucin protein determinations) were mixed with piliated RDEC-1, there were differences noted in the levels of inhibition along the intestinal tract in postweanling animals. As shown in Figure 2, inhibition of bacterial binding by mucins derived from ileal (45.1 \pm $2.6 \%$, mean $\pm \mathrm{SEM}$ ) and proximal colonic segments $(46.0 \pm$ $5.5 \%$ ) of post weanling rabbits were significantly less than mucins derived from jejunal $(70.0 \pm 2.0 \%)$ and distal colonic segments $(71.0 \pm 3.7 \%, p<0.05)$.

The extent of AF/R1 piliated RDEC-1 inhibition by equal amounts of mucin was greater for mucins derived from the proximal small intestine compared with mucins derived from the distal small intestine in suckling $(62.1 \pm 3.5 \%$ versus 37.3 $\pm 3.0 \%, p<0.01)$, weanling $(55.2 \pm 3.5 \%$ versus $35.7 \pm$ $4.6 \%, p<0.01)$, and postweanling rabbits $(70.0 \pm 2.0 \%$

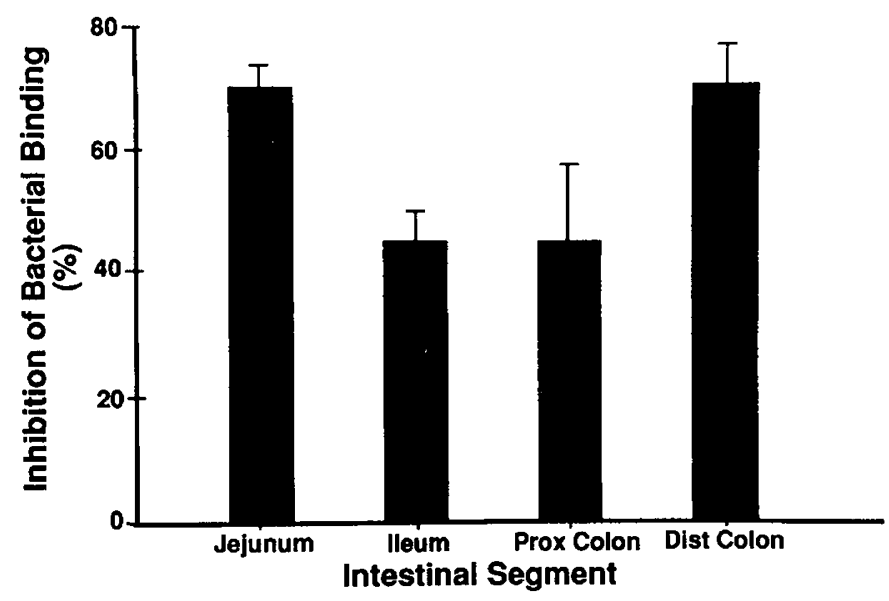

Figure 2. Inhibition of bacterial binding by mucins from postweanling rabbits. Compared with inhibition of bacterial binding by mucins derived from jejunal and distal colonic segments, RDEC-1 binding in the presence of mucin (2.5 $\mu \mathrm{g} / \mathrm{mL}$ protein) derived from ileal and proximal colon segments of intestinal tract of postweanling rabbits was significantly lower (ANOVA, $p<$ 0.05 ). Results are graphed as means with $95 \%$ confidence intervals and are based on at least 14 determinations.

versus $45.1 \pm 2.6 \%, p<0.01)$ as shown in Figure 3. There were no differences in the degree of inhibition when comparing the three age groups for mucins derived from the distal small intestine (ANOVA, $p>0.05$ ), but there was greater inhibition afforded by mucin derived from proximal small intestine of postweanling compared with weanling animals, with suckling values falling between these two age groups (ANOVA, $p<$ $0.05)$.

\section{DISCUSSION}

These experiments explored the ability of mucins to inhibit bacterial adhesion. We showed regional differences in the capacity of mucin to inhibit AF/R1-piliated RDEC-1 binding using an in vitro adhesion assay and showed that these differences were also age related. The abilities of the various mucins to inhibit in vitro adhesion corresponded to the in vivo findings for the propensity of the rabbit EPEC RDEC-1 to cause infection of the ileum and proximal colon in weanling animals $(5,25)$.

RDEC-1 (serotype $015: \mathrm{H}^{-}$) is an EPEC originally isolated in postweanling rabbits. RDEC- 1 adhere to the ileum, cecum, and colon of infected animals (25). Under transmission electron microscopy, RDEC-1 adheres to rabbit epithelial cells in vivo (26) in a manner identical with the intimate attachment of both EPEC and enterohemorrhagic $E$. coli to enterocytes in humans (27). The ability of microorganisms to adhere to epithelial cells in vitro is directly correlated with their infectivity in vivo (3). This relationship holds true for the adherence of RDEC-1 to epithelial cells in vitro and infectivity in vivo (28). Infection of rabbits with AF/R1-piliated RDEC-1 results in greater morbidity and mortality than infection with nonpiliated mutants (20). The AF/R1 pilus is a hydrophobic adhesin ligand expressed on the surface of $\operatorname{RDEC}-1(21,29)$. AF/R1 pili mediate adhesion of organisms to luminal glycoproteins (5), ileal mucins $(6), M$ cells $(30)$, and enterocytes $(18,29)$ of rabbit intestine. The importance of the AF/R1 pilus in adhesion 


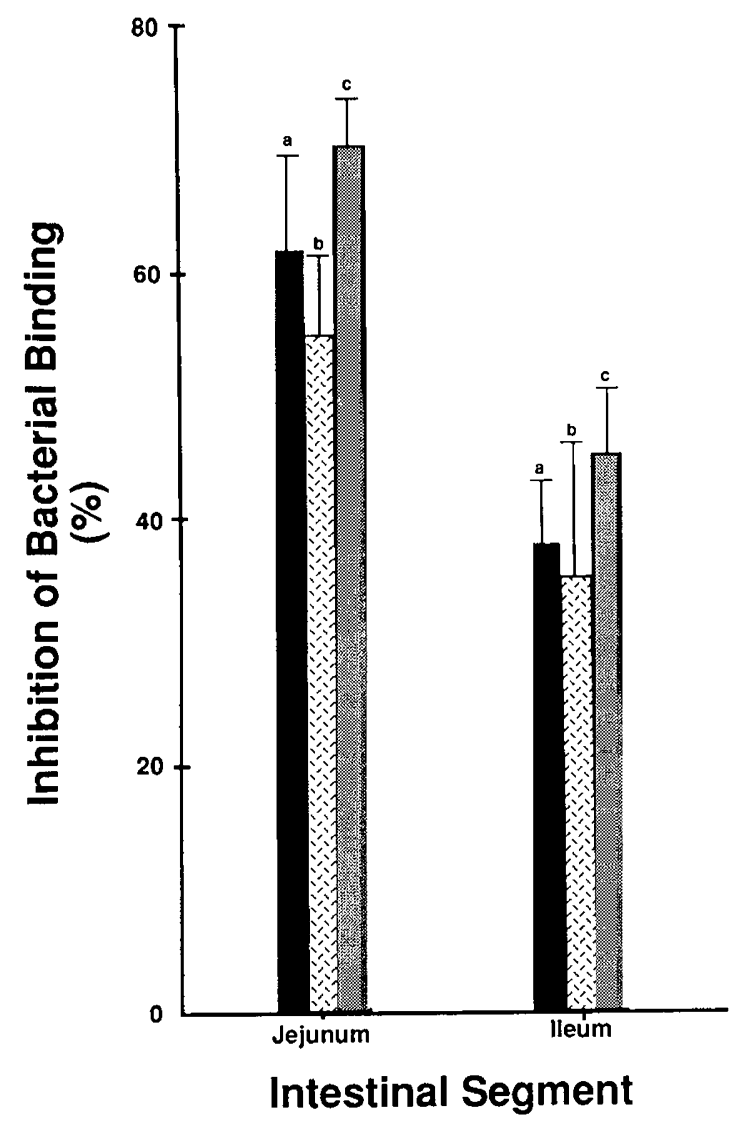

Figure 3. Age-related inhibition of bacterial binding. Inhibition of RDEC-1 binding to polystyrene wells in the presence of mucins $(2.5 \mu \mathrm{g} / \mathrm{mL}$ protein $)$ derived from jejunal segments of suckling (solid black bars), weanling (hatched bars), and postweanling (gray dotted bars) rabbits was greater in all age groups than inhibition by mucins derived from ileal segments $(a, b, c ; p<$ $0.05)$. Results are expressed as a percentage of RDEC-1 adhesion in the presence of PBS alone. Results are graphed as means with $95 \%$ confidence intervals and are based on at least 12 determinations.

was evident in the in vitro adhesion assay model system used in these experiments. Whereas increasing the size of the inoculum of AF/R1-piliated RDEC-1 led to greater binding as measured by absorbance measurements, the nonpiliated mutant strain M34 showed minimal adhesion to the polystyrene wells regardless of inoculum size. Thus, the RDEC- 1 infection in rabbits has not only been proposed to represent an animal model of human EPEC disease but the in vitro assay, which takes advantage of the hydrophobic nature of the AF/R1 pilus in binding to polystyrene, allows for evaluation of the effects of mucin on adhesion.

In vivo, adhesion of intestinal pathogens to mammalian cells is a complex process. Enteroadhesion may be mediated by both specific stereochemical interactions (i.e. receptor-ligand) and nonspecific physicochemical interactions (i.e. hydrophobicity, surface charge) $(2,3,31)$. AF/R1-piliated RDEC-1 is more hydrophobic than the nonpiliated mutant strain M34 (11). Increased hydrophobicity of mucosal surfaces in the colon could be a factor contributing to the proliferation and colonization of the bacterial microflora (32). We have previously shown that there are regional differences in surface hydrophobicity of intestinal and colonic mucosa in postweanling rabbits. Specifically, increased surface hydrophobicity of proximal and distal colonic mucosa was found compared with duodenal, jejunal, and ileal small intestinal mucosal segments. Surface tension measurements of mucus derived from ileal mucosal segments was significantly greater than surface tension measurements of mucus derived from distal colonic mucosal segments (33). Because surface tension is inversely correlated with hydrophobicity, the findings suggested that mucus could be responsible for the differences noted in the mucosal surface hydrophobicity. However, as seen in Figure 2, regions of intestinal tract in postweanling rabbits with high surface hydrophobicity (i.e. proximal colon and distal colon) (33) show both low inhibition $(45.9 \pm 5.5 \%)$ with mucin from the proximal colon and higher inhibition of bacterial binding $(71.0$ $\pm 3.7 \%$ ) with mucin from the distal colon. Also, jejunal and ileal intestinal segments were shown to be similar to each other with low surface hydrophobicity relative to surface hydrophobicity measurements of colonic segments (33) but showed high $(70.0 \pm 2.0 \%)$ and lower $(45.1 \pm 2.6 \%)$ inhibition of bacterial binding for mucin derived from jejunal and ileal segments in the present set of experiments. Thus, the hydrophobic character of surface mucosa does not appear to be the only reason for varying capacities of mucins from various regions of the intestinal tract to inhibit AF/R1-piliated RDEC-1 binding, but further confirmation will require the use of agents to block hydrophobic domains on soluble mucins or, alternatively, block hydrophobic domains on bacteria.

Specific stereochemical interactions also are important factors in in vivo adhesion of bacteria to epithelial cells. Adherence studies using RDEC- 1 indicate that this strain attaches to receptors located on host epithelial cells (34). These receptors are first detected at $21 \mathrm{~d}$ of age and by d 35 (weanling animals) have reached adult levels (35). Adhesion of EPEC to receptors on epithelial cells facilitates the ability to elicit diarrhea. Variation in expression of eukaryotic receptors has traditionally been considered to account for these age-related differences in lapine susceptibility to RDEC-1 infection. RDEC-1 has been previously shown to adhere to rabbit jejunal brushborder membranes in vitro, verifying the presence of RDEC-1 receptors in rabbit jejunum (28). However, adhesion of RDEC-1 to epithelial cells in the jejunum is not observed during in vivo infection of rabbits (28). One possible explanation for the lack of jejunal adhesion by RDEC-1 during experimental infection of rabbits is that the organisms do not have access to mucosal receptors because they are rapidly cleared from the upper intestine. Self-filling blind loops created in the jejunum to mimic stasis were inoculated with RDEC-1 and were not found to promote increased RDEC-1 mucosal attachment (25). Another possibility may be the strategic position of mucin between the intestinal luminal contents and the underlying epithelial cells. Interference with access to mucosal receptors may be one of the mechanisms by which mucins protect the underlying epithelial cells against bacterial infection. As shown in Figure 3, mucin derived from jejunal segments in all age groups showed significantly greater inhibition of bacterial binding than did mucin derived from ileal segments, thus supporting the concept of the importance of mucin in prevention of infection. 
Although this study was not designed specifically to identify the factor(s) such as apomucin isoform expression, carbohydrate composition, or posttranslational modifications such as sulfation that are responsible for mucin inhibition of RDEC-1 adhesion, some inferences may be made. It may be possible that mucin binds to an epithelial receptor used by bacteria or alternatively to specific bacterial outer membrane proteins thereby preventing the approximation of bacteria with the epithelial cell bacterial receptor. We used a polystyrene in vitro adhesion assay system that had a hydrophobic polystyrene target for AF/R1-piliated RDEC-1 bacteria. Because mucin inhibited this binding, the results suggests that mucin bound to specific bacterial proteins may be playing a more prominent role than mucin blocking epithelial receptors. The presence of Gal-GalNAc in both rat and human mucins that mimic cellular receptors to which Entamoeba histolytica lectin binds (36) suggests specific molecular mimicry of epithelial receptors within mucins. To date, a number of human mucin genes have been defined (37). Whether there is varying capacity of distinct mucin species to inhibit bacterial adhesion and whether there may be disparate regional localization of the various mucin species remain to be defined. However, the findings that the efficiency of mucins in preventing attachment of RDEC-1 varies along the intestinal tract and with age further support a specific role for mucin in mucosal host defense.

\section{REFERENCES}

1. Neutra MR, Forstner JF 1987 Gastrointestinal mucus: synthesis, secretion, and function. In: Johnson LR (ed) Physiology of the Gastrointestinal Tract, 2nd Ed. Raven Press, New York, pp 975-1009

2. Busscher HJ, Weerkamp AH 1987 Specific and non-specific interactions in bacterial adhesion to solid substrata. FEMS Microbiol Rev 46:165-173

3. Beachey EH 1981 Bacterial adherence: adhesin-receptor interactions mediating the attachment of bacteria to mucosal surfaces. J Infect Dis 143:325-345

4. Cantey JR, Inman LR, Blake RK 1977 Diarrhea due to Escherichia coli in the rabbit: a novel mechanism. J Infect Dis 135:454-462

5. Sherman PM, Boedeker EC 1987 Pilus-mediated interactions of the Escherichia col RDEC-1 with mucosal glycoproteins in the small intestine of rabbits. Gastroenterology 93:734-743

6. Drumm B, Roberton AM, Sherman PM 1988 Inhibition of attachment of Escherichia coli RDEC-1 to intestinal microvillus membranes by rabbit ileal mucus and mucin in vitro. Infect Immun 56:2437-2442

7. Mack DR, Sherman PM 1991 Mucin isolated from rabbit colon inhibits in vitro binding of Escherichia coli RDEC-1. Infect Immun 59:1015-1023

8. Colony PC, Steely J 1987 Lectin binding patterns in developing rat colon. Gastroenterology 92:1116-1126

9. Shub MD, Pang KY, Swann DA, Walker WA 1983 Age-related changes in the chemical composition and physical properties of mucus glycoproteins from rat small intestine. Biochem J 215:405-411

10. Roberton AM, Mantle M, Fahim REF, Specian RD, Bennick A, Kawagishi S, Sherman P, Forstner J 1989 The putative "link" glycopeptide associated with mucus glycoproteins. Biochem J 261:637-647

11. Mantle M, Allen A 1981 Isolation and characterization of native glycoprotein from pig small-intestinal mucus. Biochem J 195:267-275

12. Lowry OH, Rosebrough NJ, Farr AL, Randall RS 1951 Protein measurement with the Folin phenol reagent. J Biol Chem 193:265-275
13. Mantle M, Allen A 1978 A colorimetric assay for glycoproteins based on the periodic acid/Schiff stain. Biochem Soc Trans 6:607-609

14. Sambrook J, Fritsch EF, Maniatis T 1989 Commonly used techniques in molecular cloning. In: Sambrook J, Fritsch EF, Maniatis T (eds) Molecular Cloning, 2nd Ed. Cold Spring Harbor Laboratory Press, Cold Spring Harbor, NY, p E5

15. Mack DR, Gaginella TS, Sherman PM 1992 Effect of colonic inflammation on mucin inhibition of Escherichia coli RDEC-1 binding in vitro. Gastroenterology 102:11991211

16. Laemmli UK 1970 Cleavage of structural proteins during the assembly of the head of the bacteriophage T4. Nature 227:680-685

17. Merril CR, Goldman D, Sedman SA, Ebert MH 1981 Ultrasensitive stain for proteins in polyacrylamide gels shows regional variation in cerebrospinal fluid proteins. Science 211:1437-1438

18. Berendson R, Cheney CP, Schad RH, Boedeker EC 1983 Species-specific binding of purified (AF/R1) pili from Escherichia coli RDEC-1 to rabbit intestinal mucosa. Gastroenterology 85:637-645

19. Sherman PM, Houston WL, Boedeker EC 1985 Functional heterogeneity of intestinal Escherichia coli strains expressing type 1 somatic pili (fimbriae): assessment of bacterial adherence to intestinal membranes and surface hydrophobicity. Infect Immun 49:797-804

20. Wolf MK, Andrews GP, Fritz DL, Sjorgren Jr RWR, Boedeker EC 1988 Characterization of the plasmid from Escherichia coli RDEC-1 that mediated expression of adhesin $A F / R 1$ and evidence that $A F / R 1$ pili promote but are not essential for enteropathogenic disease. Infect Immun 56:1846-1857

21. Drumm B, Neumann AW, Policova Z, Sherman PM 1988 Bacterial cell surface hydrophobicity properties in the mediation of in vitro adhesion by the rabbit enteropathogen Escherichia coli RDEC-1. J Clin Invest 84:1588-1594

22. Shea C, Williamson J 1990 Rapid analysis of bacterial adhesion in a microplate assay. Biotechniques 8:610 -611

23. Schefler WC 1984 Statistics for Health Professionals. Addison-Wesley, Reading, MA

24. Winer BJ 1971 Statistical principles in experimental design. McGraw-Hill, New York

25. Sherman PM, Boedeker EC 1987 Regional differences in attachment of enteroadherent Escherichia coli strain RDEC-1 to rabbit intestine: luminal colonization but lack of mucosal adherence in jejunal self-filling blind loops. J Pediatr Gastroenterol $6: 439-444$

26. Takeuchi A, Inman LR, O'Hanley PD, Cantey JR, Lushbaugh WB 1978 Scanning and transmission electron microscopic study of Escherichia coli O15 (RDEC-1) enteric infection in rabbits. Infect Immun 19:686-694

27. Sherman P, Soni R, Karmali M 1988 Attaching and effacing adherence of verocytotoxin-producing Escherichia coli to rabbit intestinal epithelium in vivo. Infect Immun 56:756-761

28. Cheney CP, Schad PA, Formal SB, Boedeker EC 1980 Species specificity of in vitro Escherichia coli adherence to host intestinal cell membranes and its correlation with in vivo colonization and infectivity. Infect Immun 28:1019-1027

29. Cheney CP, Formal SB, Schad PA, Boedeker EC 1983 Genetic transfer of a mucosal adherence factor (R1) from an enteropathogenic Escherichia coli strain into a Shigella flexneri strain and the phenotypic suppression of this adherence factor. J Infect Dis 147:711-723

30. Inman LR, Cantey JR 1984 Peyer's patch lymphoid follicle epithelial adherence of a rabbit enteropathogenic Escherichia coli (strain RDEC-1): role of plasmid-mediated pili in intestinal adherence. J Clin Invest 74:90-95

31. Magnusson KE 1989 Physicochemical properties of bacterial surfaces. Biochem Soc Trans 17:454-458

32. Van Loosdrecht MCM, Lyklema J, Norde W, Zehnder AJB 1990 Influence of interfaces on microbial activity. Microbiol Rev 54:75-87

33. Mack DR, Neumann AW, Policova Z, Sherman PM 1992 Surface hydrophobicity of the intestinal tract. Am J Physiol 262:G171-G177

34. Rafiee P, Leffler H, Byrd JC, Cassels FJ, Boedeker EC 1991 A sialoglycoprotein complex linked to the microvillus cytoskeleton acts as a receptor for pilus (AF/R1) mediated adhesion of enteropathogenic Escherichia coli (RDEC-1) in rabbit small intestine. J Cell Biol 115:1021-1029

35. Cheney CP, Boedeker EC 1984 Rabbit mucosal receptors for an enteropathogenic Escherichia coli strain: appearance of bacterial receptor activity at weaning. Gastroenterology 87:821-826

36. Chadee K, Petri Jr WA, Innes DJ, Ravdin JI 1987 Rat and human colonic mucins bind to and inhibit adherence lectin of Entamoeba histolytica. J Clin Invest 80:1245-1254

37. Kim YS, Gum JR, Byrd JC, Toribara NW 1991 The structure of human intestinal apomucins. Am Rev Respir Dis 144:S10-S14 